Resenthas 
KUCINSKI, Meir. Imigrantes, mascates $\mathcal{E}$ doutores. (Org. e seleção) Rifka Berezin e Hadassa Cytrynowicz. São Paulo: Ateliê Editorial, 2002. 256p.

\section{Temerosos e deslumbrados: uma bistória de imigrantes}

Lyslei de Souza Nascimento I UFMG

Entre temerosos e deslumbrados, aportaram no Brasil, na esperança de reconstruir suas vidas, imigrantes judeus - bessarabianos, poloneses, alemães - todos juntos, construíram uma comunidade, resultado da aventura de homens e mulheres que acreditaram no Novo Mundo.

A organização, seleção e tradução de contos do escritor Meir Kucinski são, sem dúvida, uma contribuição, não só aos estudos judaicos no Brasil, mas também à história da literatura, da cultura e da arte que, aqui, torna-se brasileira. O sabor dos relatos, entremeado do picante e sutil humor judaico, conjuga-se, com maestria, às descrições da simplicidade da vida brasileira, das estratégias de sobrevivência, da sensualidade das mulheres e da complexa relação do imigrante com a nova terra.

A língua ídiche foi criada pelos judeus asquenazitas na Europa e cumpriu um papel fundamental na vida da diáspora ao propiciar uma ligação entre os imigrantes judeus oriundos de várias partes da Europa desde o final 
do século XIX até as primeiras metades do século XX. Os novos imigrantes deram início a uma vida cultural em língua ídiche organizando reuniões e conferências sobre literatura e música. Nos jornais impressos em ídiche, os primeiros escritores dessa nova comunidade esboçaram um olhar judaico sobre a cultura judaica e brasileira.

Os textos publicados expressavam, segundo Rifka Berezin, "a saudade do velho lar, dos familiares que lá tinham permanecido, os anseios pela vida judaica vibrante da Europa, que deixaram para trás, e também revelavam os sentimentos de solidão do recém-chegado". A luta pela sobrevivência em terra estranha era o grande tema dessas narrativas. Muitas delas tinham, nos personagens, a representação da profissão de quase todos esses imigrantes, o vendedor de porta em porta, à prestação.

Mas, entre os que aqui no Brasil aportavam, havia também escritores, artistas, intelectuais judeus de expressão ídiche que colaboravam nos jornais e, mais tarde, escreveram livros e construíram uma importante face do nosso país.

Meir Kucinski, o escritor escolhido por esse grupo de pesquisadores para, de uma certa forma, revelar ao leitor brasileiro essa face ídiche do Brasil, nasceu na Polônia em 1904. Imigrou para o Brasil em 1935, estabelecendo-se em São Paulo, onde foi professor, jornalista e escritor. Faleceu em 1976, amargurado e sofrido com o desaparecimento de sua filha Ana Rosa, professora da Universidade de São Paulo, vítima da ditadura militar.

Os contos de Kucinski revelam uma pena erudita e rigorosa. Profundo conhecedor da literatura ídiche européia, ele contribui, com espírito crítico e autônomo, para o fortalecimento de uma cultura judaica mais arejada e menos hermética. Segundo ele, alguns desses escritores não partiram para novos horizontes, não penetraram na vida brasileira, como o fizeram, por exemplo, aqueles que influenciaram o desenvolvimento da literatura norteamericana, como o escritor Scholem Asch.

A partir desse ponto de vista, é possível ler os seus contos como um mosaico de narrativas que entrecruzam uma certa tradição judaica, tipicamente européia, entremeada às cenas da vida cotidiana brasileira. Os caminhos percorridos pelos imigrantes, mascates e doutores encenam um mapa percorrido, com maestria, pelos narradores de Kucinski. Deixando confluir a nostalgia do imigrante com a necessidade de se adaptar ao Brasil, essas narrativas constroem laços que começam a ser contados, traduzidos e interpretados para 
o leitor brasileiro. Aos descendentes desses imigrantes, os contos de Kucinski soarão, talvez, como um suave rumor do passado, saudosas histórias dos pais que poderão, de repente, voltar à memória com toda sua magia, humor e nostalgia. No entanto, a voz de Kucinski atualiza nossa história, muitas vezes perdida nas dobras do tempo, nos enganos sinuosos da amnésia, e multidimensiona nossa capacidade de lembrar, e conviver, quem sabe, em harmonia, com o nosso Outro. 